Cin Şeker, Z. (2021). Türkçe öğretmeni adaylarının metindilbilim dersine ilişkin görüşleri. Ana Dili Eğitimi Dergisi, 9(4), 1226-1241.

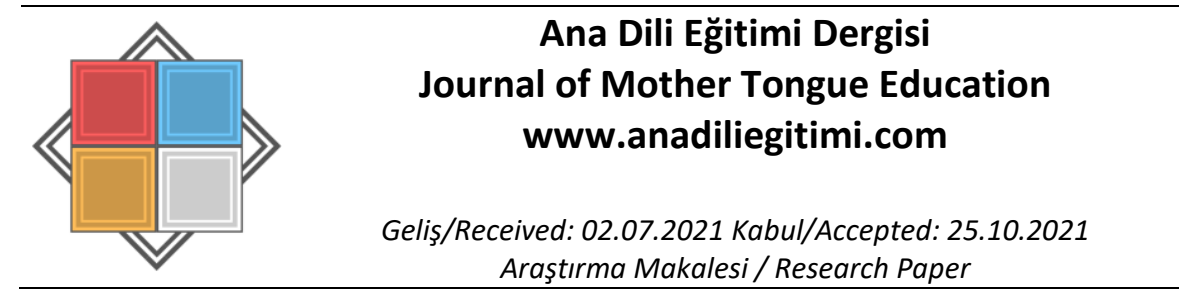

\title{
Türkçe Öğretmeni Adaylarının Metindilbilim Dersine i̇lişkin Görüşleri
}

\author{
Zeynep CIN ŞEKER*
}

\begin{abstract}
Öz
Bu çalışmanın amacı Türkçe öğretmeni adaylarının lisans eğitimi sürecinde aldıkları Metindilbilim dersine yönelik görüş ve önerilerini belirlemektir. Araştırmada nitel araştırma modellerinden temel nitel araştırma deseni kullanılmıştır. Araştırmanın çalışma grubunu Atatürk Üniversitesi Kâzım Karabekir Eğitim Fakültesi Türkçe Eğitimi Ana Bilim Dalında 2020-2021 eğitim öğretim yılında öğrenim gören ve bahar döneminde Metindilbilim dersini alan 38 öğretmen adayı oluşturmaktadır. Veri toplama aracı olarak araştırmacı tarafından hazırlanan yarı yapılandııılmış görüşme formu kullanılmıştır. Araştırma verileri içerik analizi tekniği kullanılarak çözümlenmiştir. Araştırmanın sonucunda Türkçe öğretmeni adaylarının Metindilbilim dersinin lisans programında yer almasının gerekli olduğunu düşündükleri tespit edilmiştir. Öğretmen adaylarına göre Metindilbilim dersinin, kendi metin çözümleme süreçlerine, mesleki yaşamlarında dil becerilerinin geliştirilmesi, metni anlama ve çözümleme çalışmaları, metne yönelik etkinlik tasarlama bağlamında katkı sunacağını ifade etmişlerdir. Metindilbilim dersinin teorik bilgilerle birlikte bol uygulama ve etkinlik tasarlama süreçlerini de içermesi gerektiğini belirten öğretmen adayları, ders süresinin artırılması ve ders içeriğinde farkı metin türlerine yönelik daha fazla uygulama ile karşılaşmak istediklerini vurgulamışlardır.
\end{abstract}

Anahtar Kelimeler: Türkçe öğretmeni adayları, metindilbilim dersi, Türkçe eğitimi

\begin{abstract}
Opinions of Turkish Teacher Candidates on Textlinguistics Course
\section{Abstract}

The aim of this study is to determine the opinions and suggestions of Turkish teacher candidates about the Textlinguistics course they took during their undergraduate education. In the research, basic qualitative research design, one of the qualitative research models, was used. The study group of the research consists of 38 teacher candidates studying at Atatürk University Kazım Karabekir Faculty of Education, Department of Turkish Education in the 2020-2021 academic year. A semi-structured interview form prepared by the researcher was used as a data collection tool. Research data were analyzed using content analysis technique. As a result of the research, it was determined that Turkish teacher candidates think that the Textlinguistics course should be included in the undergraduate program. According to the pre-service teachers, they stated that the Textlinguistics course would contribute to their text analysis processes in the context of developing language skills in their professional life, understanding and analyzing the text, and designing activities for the text. Pre-service teachers, who stated that the text linguistics course should include theoretical knowledge as well as plenty of practice and activity design processes, stated that the duration of the course should be increased and more applications should be made for different types of text in the course content.
\end{abstract}

Keywords: Turkish teacher candidate, textlinguistics course, Turkish education

\footnotetext{
* Dr. Öğr. Üyesi, Atatürk Üniversitesi, Kâzım Karabekir Eğitim Fakültesi, Türkçe ve Sosyal Alanlar Eğitimi Bölümü, Türkçe Eğitimi Ana Bilim Dalı, zeynep.seker@atauni.edu.tr, ORCID: 0000-0002-0294-2961
} 


\section{Giriş}

Eğitim sistemi, birçok farklı bileşenin ortak işleyişiyle oluşur. Sistem içerisindeki bileşenlerin niteliği eğitimin niteliğini de belirler. Kavcar'a (2002) göre öğretmen eğitim sisteminin en önemli ögesidir ve nitelikli bir eğitimin temelinde nitelikli öğretmenler vardır. Sönmez'e (2007) göre öğretmenlik özel bilgi, beceri ve ilgi isteyen, önemli bir meslektir. Bu bağlamda öğretmen eğitimi önemli bir konu olarak karşımıza çıkmaktadır. Öğretmen eğitiminde ise öğretmenin nitelikli hâle gelmesinde önemli rol oynayan etkenlerden ilki öğretmen adaylarına uygulanan hizmet öncesi eğitim programı yani lisans eğitimidir (Işık, Çiltaş ve Baş, 2010). Bütün öğretmenlik alanlarında olduğu gibi Türkçe öğretmenlerinin donanımlı biçimde yetiştirilmesi hizmet öncesi eğitim olarak kabul edilen lisans programlarında yer alan derslere ve ders içeriklerine bağlıdır.

Türkçe Öğretmenliği Ana Bilim Dalı lisans programı olarak ilk defa, 1992-1993 eğitim öğretim yılında Gazi Üniversitesi Türk Dili ve Edebiyatı Eğitimi Bölümü bünyesinde açılmıştır (Güzel, 2003). 1998-1999 eğitim öğretim yılında YÖK eğitim fakültelerini yeniden yapılandırmış ve uygulanan yeni sistemle birlikte Eğitim Fakültelerinde Türkçe, Matematik, Fen Bilgisi, Sosyal Bilgiler, İngilizce biçiminde 16 programla tekrardan düzenlenmiştir (Türer, 2006'dan akt. Yalap, Demirgüneş ve Akay, 2020). 2006 yılında yapılandırmacı yaklaşımı temel alan Türkçe Dersi Öğretim Programı́nın yayınlanmasıyla birlikte Türkçe öğretmenliği lisans eğitimi programında da değişikliğe gidilmiştir. Birçok farklı öğretmenlik alanı ile birlikte Türkçe öğretmenliği lisans programında son olarak 2018 yılında değişiklik yapılmıştır.

Yalap, Demirgüneş ve Akay’a (2020) göre ana dili öğreticilerinin, anadillerini her yönüyle yeni nesillere öğretebilmesinde en önemli aşamalardan biri, üniversitelerdeki Türkçe eğitimi meselesidir ve Türkçe eğitiminin içeriğinde dil felsefesi, edebiyat, dilbilim, tarih ve kültür gibi alanlardan faydalanmak da zorunlu bir durumdur. Türkçe eğitimi, bilgi öğretimi olmaktan çok beceri temelli bir eğitimdir. Dil bilgisinin ayrı bir alan olarak öğretildiği geleneksel yaklaşımların yerine dil bilgisinin temel dil becerilerinin geliştirilmesi sürecinde bir araç olduğunu ifade eden çağdaş yaklaşımlar tercih edilmelidir. Aynı zamanda "dil ile düşünce arasındaki doğal ilişki dikkate alındığında dil eğitiminin aynı zamanda bir düşünme eğitimi olduğu sonucuna varılır." (Börekçi, 2009, s. 422). Bu bağlamda Türkçe öğretmenlerinin yetiştirilmesine aracı olan lisans programlarında Türkçe öğretmeni adaylarının dil ve düşünme becerilerine yönelik alan bilgisine sahip olmaları ve bu alan bilgisini beceriye dönüştürmelerini sağlayacak derslerle ve ders içerikleriyle karşılaşmaları önemlidir.

\section{Metindilbilim ve Türkçe Öğretimi}

Yapılandırmacı yaklaşımı temel alan 2006 Türkçe Dersi Öğretim Programı́nda (MEB, 2006), öğrencilerin kazanımlar ve etkinlikler yoluyla dinleme/izleme, konuşma, okuma, yazma becerilerini geliştirmeleri, dilimizin imkân ve zenginliklerinin farkına vararak Türkçeyi doğru, güzel ve etkili kullanmaları hedeflendiği ifade edilmektedir. Aynı programda dil bilgisiyle ilgili kazanımların değerlendirilmesinde kuralların metin veya cümle bütünlüğü ve bağlamı içerisinde ele alınmasının diğer becerileri desteklemesi açısından oldukça önemli olduğu belirtilmiştir. Programın dil bilgisiyle ilgili açıklamalarında, dil bilgisinin kurallarını tanımlayan bilgilere sahip olmanın önemine vurgu yapılmış aynı zamanda bu bilgilerin konuşma, yazma, dinleme ve okuma becerileri ile ilişkili dil etkinliklerinde uygulanmasının daha önemli olduğu ifade edilmiş ve dil bilgisinin kelime, cümle ve metin düzeyinde uygulamaları amaçlanmıştır. Bu bağlamda dil bilgisinin bağlamdan kopuk, kurallar yığını olmaktan çıkarılıp uygulama boyutunda araç olarak kullanılmasının gerekliliği ve metinlerin Türkçe derslerindeki yeri ön plana çıkmaktadır.

Türkçe eğitimi sürecinde karşılaşılan temel sorunlardan biri, dilin kullanım yani iletişimsel boyutunun göz ardı edilmesidir. Çağdaş dil öğretim yaklaşımları, dil öğretiminde dilin kullanım boyutunu ön planda tutarak temel dil biriminin metin olması gerektiğini savunur. Kavcar (1993, s. 35) da çağdaş dil öğretiminde kullanılacak temel yöntemin, öğretimi metinlere dayandırmak, öğrenciyi farklı metinlerle karşılaştırmak ve metinlerin dünyasında yaşatmak olduğunu söyler.

Nitelikli metin seçimi, öğretimin niteliğini belirleyecek temel etkenlerden biriyken seçilen metinlere hangi yöntemlerle yaklaşılması gerektiği önemli bir sorun olarak karşımıza çıkmaktadır. Dilidüzgün (2013), metnin anlamını oluşturan dil öğeleri arasındaki ilişkileri saptamanın ve metni işlevsel parçalara ayırabilmenin, metnin çözümlenmesi ve değerlendirilebilmesi için şart olduğunu 
belirtir. Metinlere yönelik etkinliklerin ise her metinde farklılaşan ve her metnin türüne özgü ilişkileri açığa çıkaran içerikte ve özellikte olması gerektiğini vurgular. Metinlerin işlevsel kullanımının, öğrencilerin dil yapılarını bağlam içerisinde görmeleri, dil yapılarının anlam ile ilişkisini kavramaları ve anlam kurma sürecini bu doğrultuda yapılandırmaları bakımından önem taşımaktadır. Bu bağlamda "metinlerin yapılarını, yani dil bilgisel ve içeriksel kurgulanış biçimlerini ve bildirişimsel işlevlerini ortaya çıkarma ve uygulamalı örneklerle gösterme" (Şenöz Ayata, 2005, s. 22) amacında olan metindilbilimin olanaklarından faydalanmak gerekir.

Metindilbilimin işlevlerinden biri, metin olanla olmayanı belirli ölçütler çerçevesinde belirlemektir. Bir diğer önemli işlevi ise dil bilgisel yapılardan hareketle metnin anlamına ulaşmaktır. Dil bilgisel yapılar, metnin derin düzeyinde yer alan zihinsel tasarımların yüzeysel yapıya taşınmış biçimleridir. Onan’a (2015) göre “bir dilin, yüzey yapısını oluşturan özellikler, o dilin dil bilgisi kurallarını oluşturmaktadır. Bir dili öğrenme sürecinde sadece yüzey yapı kurallarına odaklanmak yeterli değildir. Derin yapı yüzey yapı ilişkilerinde de bir eşgüdümün sağlanması gerekmektedir.". Metindilbilim metni çözümlerken öncelikle dil bilgisel yapıları ortaya çıkarır ve bu yapıların metnin büyük ölçekli yapısında oluşturduğu anlama ulaşır. Metindilbilimin bu özelliği, öğrencilerin metnin yüzeysel düzeyini temsil eden dil bilgisel bileşenlerle, metnin derin düzeyini temsil eden anlamsal bileşenler arasında bir ilişki olduğunu kavramasını kolaylaştırır.

Metindilbilim ve Türkçe eğitimi arasındaki ilişkiye bakıldığında Türkçe derslerinin yürütülmesini sağlayan Türkçe öğretmenlerinin metindilbilimin Türkçe eğitimine katkısını fark edecek ve metindilbilim araçlarını derslerinde kullanabilecek bilgi ve becerilere sahip olmalarının büyük önem taşıdığı söylenebilir.

\section{Türkçe Öğretmenliği Lisans Programlarında Metindilbilim Dersinin Yeri}

Türkçe öğretmenliği lisans programları incelendiğinde metindilbilimle ilişkili ders ve ders içeriklerinin programlarda yer aldığı görülmektedir. 1998-1999 eğitim öğretim yılında uygulanmaya başlanan programda "alan derslerinin ağırlığı \%46, Genel Kültür \%31 ve Meslek Bilgisi \%23 olarak karşımıza çıkmaktadır." (Yalap, Demirgüneş ve Akay, 2020, s. 235). Programda doğrudan metindilbilim dersine yer verilmemiştir ancak V. yarıyılda metindilbilimle ilişkilendirilebilecek "Metin Bilgisi" dersine yer verilmiştir. Ders içerikleri şu şekildedir:

Tablo 1.

1998 Türkçe Öğretmenliği Lisans Programında Yer Alan Metindilbilim ile ilişkilendirilebilecek Dersler

\begin{tabular}{ccl}
\hline \multicolumn{1}{c}{ Ders Adı } & Yarıyıl & Ders içeriği \\
\hline Metin Bilgisi & V & $\begin{array}{l}\text { Metin seçimi, metnin yaş grubuna göre güçlük derecesinin belirlenmesi, } \\
\text { metnin dış yapısının (punto, sayfa düzeni, vb.) kontrol edilmesi, metinle } \\
\text { ilgili soruların hazırlanması ve değerlendirilmesi, paragraf analizi, metnin } \\
\text { çeşitli yönlerden değerlendirilmesi ve metin çalışmaları (YÖK, 1998, s. 52). }\end{array}$ \\
\hline Dil ve Kültür & IV $\quad \begin{array}{l}\text { Kültürün tanımı, dil ve kültür ilişkisi, dil, edebiyat ve kültür ilişkilerinin } \\
\text { edebi metinler yoluyla incelenmesi, dilin ve edebi metinlerin kültürel } \\
\text { boyutları, dilbilim ve dalları (YÖK, 1998, s. 53). }\end{array}$ \\
\hline
\end{tabular}

"Metin Bilgisi" dersinin, Türkçe öğretmeni adaylarının, öğrencilerinin yaş ve seviyesine uygun metin seçme, metinlere yönelik soru hazırlama, metnin dış yapısına yönelik özellikleri değerlendirme, metni genel olarak değerlendirme becerilerini geliştirmeye yönelik bir içeriğe sahip olduğu görülmektedir. Metin çalışmaları olarak ifade edilen bölümün açıklaması yapılmamıştır. 'Metin Bilgisi' dersinin programda olması önemsenmekle birlikte ders içeriğinin metnin yorumlanmasını, çözümlenmesini ve anlamlandırılmasını sağlayacak nitelikte detaylandırılmadığı söylenebilir. Aynı programda yer alan "Dil ve Kültür" dersinin içeriği incelendiğinde 'dilbilim ve dalları' başlığına yer verilmiştir. Bu başıkla ilişki olarak dilbilim ve dallarının, teorik olarak ele alındığı düşünülmektedir. 
Tablo 2.

2007 Türkçe Öğretmenliği Lisans Programında Yer Alan Metindilbilim ile ilişsilendirilebilecek Dersler

\begin{tabular}{|c|c|c|}
\hline Ders adı & Yarıyıl & Dersin İçeriği \\
\hline Yazılı anlatım I & 1 & $\begin{array}{l}\text { Yazı dilinin ve yazılı iletiş̧imin temel özellikleri, yazı dili ile sözlü dilin } \\
\text { arasındaki temel farklar. Anlatım: yazıı ve sözlü anlatım; öznel } \\
\text { anlatım, nesnel anlatım; paragraf; paragraf türleri (giriş-gelişme- } \\
\text { sonuç paragrafları). Metnin tanımı ve metin türleri (bilgilendirici } \\
\text { metinler, yazınsal metinler); metin olma koşulları (bağlaşıklık, } \\
\text { tutarlılı, amaçlılık, kabul edilebilirlik, durumsallık, bilgisellik, } \\
\text { metinlerarası ilişkiler). Yazıı anlatım (konu, konunun } \\
\text { sınırlandırılması, amaç, bakış açısı, ana ve yan düşüncelerin } \\
\text { belirlenmesi; yazma planı hazırlama, kâğıt düzeni); bilgilendirici } \\
\text { metinler (dilekçe, mektup, haber, karar, ilan/reklam, tutanak, } \\
\text { rapor, resmi yazılar, bilimsel yazılar) üzerinde kuramsal bilgiler; } \\
\text { örnekler üzerinde çalışmalar ve yazma uygulamaları; bir metnin } \\
\text { özetini ve planını çıkarma; yazılı uygulamalardaki dil ve anlatım } \\
\text { yanlışlarını düzelttme. }\end{array}$ \\
\hline Yazılı Anlatım II & II & $\begin{array}{l}\text { Yazılı anlatımda düşünceyi temellendirme yolları (tanımlama, } \\
\text { örneklendirme, karşılaştırma, tanık gösterme, alıntı yapma, } \\
\text { istatistiklerden yararlanma); anlatım biçimleri (açıklayıcı, } \\
\text { tartışmacı, betimleyici, öyküleyici anlatım); bunlar üzerinde } \\
\text { kuramsal bilgiler, örnekler üzerinde çalışmalar ve yazma } \\
\text { uygulamaları. Bilgilendirici metinler (makale, köşe yazısı, söyleşi, } \\
\text { fıkra, deneme, eleştiri, günlük, anı, gezi yazısı, yaşamöyküsü, } \\
\text { özyaşamöyküsü v.b.) üzerinde kuramsal bilgiler, örnekler üzerinde } \\
\text { çalışmalar ve yazma denemeleri. Yazınsal metinler (şiir, öykü, } \\
\text { roman, oyun, deneme vd) üzerinde kuramsal bilgiler; örnekler } \\
\text { üzerinde çalışmalar ve yazma uygulamaları; yazılı uygulamalardaki } \\
\text { dil ve anlatım yanlışlarını düzeltme. }\end{array}$ \\
\hline Genel Dilbilim & IV & $\begin{array}{l}\text { Dilbilim kavramı ve dilbilimin temel kavramları. Saussure ve } \\
\text { yapısalcılık, Avrupa (Prag dilbilim okulu) ve Amerikan yapısalcılığı, } \\
\text { sözcelem kuramları, göstergebilim gibi çeşitli alanların dil } \\
\text { incelemeleriyle ilgili yaklaşımlarının tanıtılması. Dilbilim } \\
\text { çalışmalarına yön veren önemli kişiliklerin (Martinet, Bloomfield, } \\
\text { Harris, Hjelmslev, Chomsky vb.) çalışmalarıyla birlikte ele alınması. } \\
\text { Betimsel boyutun yanı sıra dilin kullanımına yönelik edimbilimsel } \\
\text { çözümlemelerin de yapılması. }\end{array}$ \\
\hline
\end{tabular}

2007 programında yer alan Yazılı Anlatım I/II derslerinin içeriğinde metindilbilimle ilişkili kavramların olduğu görülmektedir. Börekçi'ye (2009) göre ana dili öğrenimi/öğretimi sürecinin bir parçası olarak uygulanan yazılı anlatım etkinlikleri, farkında olmadan kazanılmış dil yapılarının yani "edinç" in bilinçle oluşturulan dil yapılarına yani "edim"e dönüşmesini sağlamaya yönelik olmalıdır. Bu bağlamda metindilbilim kavramlarının, Metindilbilim dersi biçiminde Türkçe Öğretmenliği Programı́na yansıtılması verimli olacaktır.

Tablo 3.

2018 Türkçe Öğretmenliği Lisans Programında Yer Alan Metindilbilim ile ilişkilendirilebilecek Dersler

\begin{tabular}{lll}
\hline Ders adı & Yarıyılı & Ders içeriği \\
\hline Tük Dili I & Yazı dili ve özellikleri; yazım ve noktalama; yazılı ve sözlü anlatımın \\
& । & $\begin{array}{l}\text { özellikleri; paragraf oluşturma ve paragraf türleri (giriş, gelişme, } \\
\text { sonuç paragrafları); düşünceyi geliştirme yolları (açılama, tartışma, }\end{array}$ \\
\hline
\end{tabular}




\begin{tabular}{|c|c|c|}
\hline & & $\begin{array}{l}\text { öyküleme, betimleme; tanımlama, örneklendirme, tanık gösterme, } \\
\text { karşılaştırma vb. uygulamaları); metin yapısı (metnin yapısal } \\
\text { özellikleri, giriş-gelişme-sonuç bölümleri); metinsellik özellikleri } \\
\text { (bağlaşıklık, tutarlılık; amaçlılık, kabul edilebilirlik, durumsallık, } \\
\text { bilgisellik, metinlerarasılık); metin yazma (taslak oluşturma, yazma, } \\
\text { düzeltme ve paylaşma); bilgilendirici-açıklayıcı metin yazma; } \\
\text { öyküleyici metin yazma; betimleyici metin yazma; tartışmacı ve ikna } \\
\text { edici metin yazma. }\end{array}$ \\
\hline $\begin{array}{l}\text { Dil Eğitiminin Temel } \\
\text { Kavramları }\end{array}$ & II & $\begin{array}{l}\text { Dil eğitiminin kavram alanını oluşturan başlıca disiplinler. Dil } \\
\text { eğitiminin temel kavramları; okuma, dinleme, yazma, konuşma } \\
\text { eğitimiyle ilgili kavramlar; metin bilgisi, kelime hazinesi ve dil bilgisi } \\
\text { ile ilgili kavramlar. Dil eğitimiyle dolaylı ilişkisi olan alanlardan } \\
\text { (edebiyat, iletişim, felsefe, sosyoloji, psikoloji, bilişsel bilimler vb.) } \\
\text { dil eğitimine aktarılan kavramlar. }\end{array}$ \\
\hline Metindilbilim & VI & $\begin{array}{l}\text { Metindilbilimin temel ilke ve kavramları (tümce, önerme, sözce; } \\
\text { metin ve metinsellik ölçütleri: üretici/metin ve alıcı merkezli), metin } \\
\text { türü, söylem ve metin türü sınıflamaları; metin türlerinin dilsel } \\
\text { görünümleri; anlatı söylemi, anlatı metinleri ve dil aktarımı; söz } \\
\text { eylem kuramı. }\end{array}$ \\
\hline
\end{tabular}

2018 programında Türk Dili I dersinin içeriği incelendiğinde metindilbilim ile ilişkili konu başlıklarına yer verildiği görülmektedir. Ders içeriğinde metin olma koşullarının yanında metin oluşturma çalışmaları yer almaktadır. Dil Eğitiminin Temel Kavramları adlı dersin içeriğinde ise metin bilgisi başlğına yer verilmiştir. Öğretmen adaylarının, I. ve II. dönemde aldıkları bu derslerle metin kavramına bilimsel bir bakış geliştirmenin temelini atacakları söylenebilir.

Türkçe öğretmeni adayları Vı. Dönemde Metindilbilim dersiyle karşılaşmaktadır. Dersin içeriği metin kavramına metindilbilimsel bir yaklaşıma olanak sağlayacak niteliktedir. Ancak dersin, metindilbilimin olanaklarından Türkçe eğitimi bağlamında yararlanmayı gerçekleştirecek uygulama ve metindilbilimsel etkinlik tasarlama açısından eksik olduğu ifade edilebilir.

Şenöz Ayata (2005, s. 57) öğrencilerin bir metinde yer alan bilgilerin nasıl kurgulandığını, metin yapısının metnin işlevi ile nasıl ilişkilendirildiğini kavramalarının ve metindeki temel bilgilere ulaşma, metinleri doğru okuma-anlama ve doğru metin üretme becerilerinin geliştirilmesinin gerekli olduğunu ifade eder. Aynı zamanda bu becerilerin gelişmesi için metin türlerine yönelik genel ve karakteristik özellikleri ortaya çıkarma becerilerinin geliştirilmesinin de önemli olduğunu vurgular. Bu bağlamda metinleri, metindilbilimsel anlayışla çözümlemenin ve Türkçe öğretmeni adaylarının da metindilbilimsel çözümlemenin olanaklarından faydalanmalarını sağlayacak derslerle ve içeriklerle karşılaşmaları önemlidir. Çünkü "metindilbilim alanının kuramsal yönelimi ve gelişim çizgisindeki çok yönlülüğü, özellikle ana dili öğretimi sürecinde metin kavramının ayrıntılı olarak ele alınmasını sağlamaktadır." (Çıkrıkçı, 2007).

Alan yazın incelendiğinde Türkçe öğretmenliği lisans programını değerlendiren, Türkçe öğretmeni adaylarının ve öğretim elemanlarının lisans programına yönelik görüş ve önerilerini belirlemeye çalışan araştırmalara rastlanmaktadır (Çoban, 2010; Durukan ve Maden, 2011; Özkan ve Şahbaz, 2011; Stebler ve Aykaç, 2019; Yalap, Demirgüneş ve Akay, 2020). Türkçe öğretmenliği lisans programını bütüncül olarak değerlendiren çalışmaların yanında anlama ve anlatma becerileri (Özkan, 2010; Ceran, 2012; Ceran, 2013; Sevim ve Şeref, 2015; Eyüp, 2019), Çocuk Edebiyatı (Yılmaz, 2016), Cümle Bilgisi (Hirik, 2018), Osmanlı Türkçesi (Kahya, 2020), Türkçe Özel Öğretim Yöntemleri (Akyüz, Özcan ve Altıparmak, 2015), Tiyatro ve Drama Uygulamaları (Doğan ve Özberk, 2013), Medya Okuryazarlığı (Kansızoğlu, 2016), Öğretim Teknolojileri ve Materyal Tasarımı (Ürün Karahan, 2016), Öğretmenlik Uygulaması (Tüm, 2016) ve Topluma Hizmet Uygulamaları (Sevim, 2011) derslerine ilişkin Türkçe öğretmeni adaylarııın görüş, öneri ve tutumlarını inceleyen çalışmalar da yapılmıştır. 
1998 Türkçe öğretmenliği lisans programında Metin Bilgisi, 2018 programında ise Metindilbilim adıyla yer alan ve metindilbilimin Türkçe öğretmenlerinin alan bilgisine katkı sunmayı amaçlayan dersler üzerine Türkçe öğretmeni adaylarının görüş ve önerilerini belirlemeye çalışan araştırmalara rastlanmamıştır. Börekçi (2009) Türkçe öğretmenlerinin yetiştirilmesinde dilbilimin olanaklarından faydalanmanın önemli olduğunu vurguladığı çalışmasında Metindilbilim dersinin gerekliliğine vurgu yapmıştır. Bu bağlamda Metindilbilim dersini alan öğretmen adaylarının ders ile ilgili görüşleri, dersin amacına ulaşıp ulaşmadığını belirleme ve dersi daha işlevsel hâle getirme bağlamında önem taşımaktadır. Bu doğrultuda çalışmanın alt problemleri şöyledir:

1. Türkçe öğretmeni adaylarının Metindilbilim dersinin Türkçe öğretmenliği lisans programında yer almasına ilişkin görüşleri nelerdir?

2. Türkçe öğretmeni adaylarının Metindilbilim dersinde edikleri bilgi, beceri ve deneyimlerin mesleki yaşamlarına katkısına yönelik görüşleri nelerdir?

3. Türkçe öğretmeni adaylarının Metindilbilim dersinin kendi metin çözümleme süreçlerine katkısına yönelik görüşleri nelerdir?

4. Türkçe öğretmeni adaylarının Metindilbilim dersine ayrılan süreye ilişkin görüşleri nelerdir?

5. Türkçe öğretmeni adaylarının Metindilbilim dersine yönelik önerileri nelerdir?

\section{Araştırmanın Modeli}

\section{Yöntem}

Bu çalışmada, nitel araştırma modellerinden temel nitel araştırma deseni kullanılmıştır. Nitel araştırma, sosyal ya da beşeri bir probleme bireylerin atfettiği anlamları keşfetme ve anlamaya yönelik bir yaklaşımdır (Creswell, 2017). Bütün nitel araştırmalar anlamın nasıl inşa edildiğiyle, insanların hayatlarını ve dünyalarını nasıl anlamlandırdıklarıyla ilgilidir. Nitel temel desenin öncelikli amacı bu anlamları açığa çıkarmak ve yorumlamaktır (Merriam, 2018). Bu bağlamda Türkçe öğretmeni adaylarının Metindilbilim dersine yönelik görüşlerini belirlemek amacıyla temel nitel araştırma deseni kullanılmıştır.

\section{Araştırma grubu}

Araştırmanın çalışma grubu amaçlı örnekleme yöntemlerinden kolay ulaşılabilir durum örneklemesi ile oluşturulmuştur. Bu örnekleme yöntemi araştırmaya hız ve pratiklik kazandırmaktadır. Çünkü bu yöntemde araştırmacı, yakın olan ve erişilmesi kolay olan bir durumu seçer (Yıldırım ve Şimşek, 2000). Araştırmanın çalışma grubunu Atatürk Üniversitesi Kâzım Karabekir Eğitim Fakültesi Türkçe Eğitimi Ana Bilim Dalında 2020-2021 eğitim öğretim yılında öğrenim gören ve bahar döneminde Metindilbilim dersini alan 38 öğretmen adayı oluşturmaktadır. Metindilbilim dersi 3. sınıfta yer aldığı için araştırmaya 3. sınıfta öğrenim gören Türkçe öğretmeni adayları dâhil edilmiştir.

\section{Veri Toplama Araçları}

Araştırma verileri görüşme tekniği ile toplanmıştır. Veri toplama aracı olarak araştırmacı tarafından hazırlanan yarı yapılandırılmış görüşme formu kullanılmıştır. Form hazırlanmadan önce alan yazın taraması yapılmış, Metindilbilim dersine ve lisans derslerine ilişkin görüş belirlemeyi amaçlayan çalışmalar taranmış ve 2 Türkçe eğitimi alan uzmanının görüşüne başvurulmuştur. Ön çalışma sonrasında yarı yapılandırılmış görüşme formu oluşturulmuştur. Görüşme formu öncelikle 3 öğrenciye gönderilmiş ve formda yer alan soruların anlaşılmayan ve açık olmayan bölümleri öğrenci dönütlerinden hareketle belirlenmiş ve düzenlenmiştir. Son şekli verilen formda 5 açık uçlu soruya yer verilmiştir. Sorular şöyledir:

1. Metindilbilim dersinin Türkçe öğretmenliği lisans programında yer almasını gerekli görüyor musunuz? Neden?

2. Metindilbilim dersinde edindiğiniz bilgi, deneyim ve becerilerin meslek yaşamınıza katkı sunacağını düşünüyor musunuz? Açıklayınız.

3. Metindilbilim dersi kendi metin çözümleme süreçlerinize katkı sundu mu? Açıklayınız.

4. Metindilbilim dersine ayrılan süreyi yeterli buluyor musunuz? Neden?

5. Metindilbilim dersinin daha işlevsel olabilmesi için önerileriniz nelerdir? Açıklayınız. 


\section{Verilerin Toplanması}

Yarı yapılandırılmış görüşme formu içinde bulunduğumuz salgın süreci dikkate alınarak Google Forms aracılığıyla öğrencilere ulaştırılmıştır. Öğrencileri formdaki soruları yanıtlamaları için belirli bir süre verilmemiş, forma katılımın bittiği 4. günün sonunda veri toplama süreci sonlandırılmıştır.

\section{Verilerin Analizi}

Araştırma verileri içerik analizi tekniği kullanılarak çözümlenmiştir. İçerik analizinde amaç, toplanan verileri açıklayabilecek kavramlara ve ilişkilere ulaşmaktır (Yıldırım ve Şimşek, 2000). iç̧erik analizi, desen, tema, varsayım ve anlamlar çıkarma çabası içinde, belirli miktarda materyalin dikkatli, ayrıntılı, sistematik bir biçimde incelenmesi ve bir kodlama, veri yorumlama sürecidir (Berg ve Lune, 2019). Araştırmanın geçerliğini ve güvenirliğini sağlamak için öğretmen adaylarının görüşleri araştırmacı ve bir alan uzmanı tarafından kodlanmıştır. Kodlamalar arasındaki tutarııı̆ın \%95 olduğu tespit edilmiştir. Kodlamalar arasında benzer olanlar bir araya getirilmiş farklı olanlar ise aynı şekilde korunmuştur. Ardından kodlar, frekans ve yüzde değerleri tablo biçiminde ifade edilmiştir. Araştırmaya katılan Türkçe öğretmeni adaylarının görüşlerinin hangi kodla ilişkili olduğu da katılımcı kodları ile gösterilmiştir. Türkçe öğretmeni adayları ÖA1, ÖA2, ÖA3... şeklinde kodlanmıştır.

\section{Araştırma ve Yayın Etiği}

Bu çalışmada "Yükseköğretim Kurumları Bilimsel Araştırma ve Yayın Etiği Yönergesi" kapsamında uyulması belirtilen tüm kurallara uyulmuştur. Yönergenin ikinci bölümü olan "Bilimsel Araştırma ve Yayın Etiğine Aykırı Eylemler" başlığı altında belirtilen eylemlerden hiçbiri gerçekleştirilmemiştir.

\section{Etik Kurul İzi}

Kurul adı = Atatürk Üniversitesi Eğitim Bilimleri Enstitüsü Birim Etik Kurulu

Karar tarihi $=07.06 .2021$

Belge sayı numarası= E-29202147-300-2100147236- 06/10 sayılı karar

\section{Bulgular}

Bu bölümde, Türkçe öğretmenliği lisans programında yer alan Metindilbilim dersine yönelik Türkçe öğretmeni adaylarının görüşleri tablolar hâlinde sunulmuştur.

Türkçe öğretmeni adaylarının Metindilbilim dersinin Türkçe öğretmenliği lisans programında yer almasına ilişkin görüşleri Tablo 4'te yer almaktadır.

Tablo 4.

Türkçe Öğretmeni Adaylarının Metindilbilim Dersinin Lisans Programında Yer Almasına Yönelik Görüşleri

\begin{tabular}{|c|c|c|c|}
\hline Görüşler & Katılımcılar & $\mathrm{f}$ & $\%$ \\
\hline Türkçe öğretmenliği sürecinde kullanılacak bilgiler sunma & 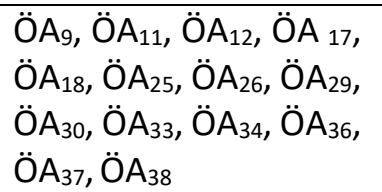 & 14 & 29,2 \\
\hline Metin odaklı Türkçe eğitimine katkı sağlama & 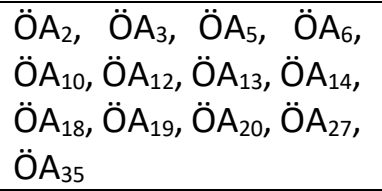 & 13 & 27,1 \\
\hline $\begin{array}{l}\text { Metin kavramı ile ilgili yeni bilgiler sunma, metin } \\
\text { kavramına yönelik yanlış öğrenmeleri düzeltme }\end{array}$ & $\begin{array}{l}K_{10}, O ̈ A_{13}, O ̈ A_{21}, O ̈ A_{22} \\
\ddot{O ̈}_{23}, O_{32}\end{array}$ & 6 & 12,5 \\
\hline $\begin{array}{l}\text { Metinleri anlama, anlamlandırma ve çözümleme sürecine } \\
\text { katkı sunma }\end{array}$ & 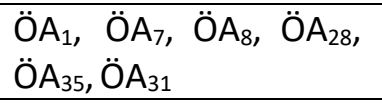 & 6 & 12,5 \\
\hline
\end{tabular}




\begin{tabular}{llcc}
\hline $\begin{array}{l}\text { Okuma becerisi kazanımlarını gerçekleştirme becerisi } \\
\text { kazandırma }\end{array}$ & $\mathrm{ÖA}_{15}, \mathrm{Ö}_{16}, \mathrm{Ö}_{28}$ & 3 & 6,3 \\
\hline Metin türü farkındalığı kazandırma & $\mathrm{ÖA}_{4}, \ddot{O ̈}_{27}$ & 2 & 4,1 \\
\hline $\begin{array}{l}\text { Ortaokulda yer alan metin üretme etkinlikleri tasarlama } \\
\text { sürecine katkı sunma }\end{array}$ & $\mathrm{ÖA}_{7}, \ddot{O ̈}_{16}$ & 2 & 4,1 \\
\hline Metinlere yönelik etkinlik tasarlama sürecine katkı sunma & ÖA $_{24}$ & 1 & 2,1 \\
\hline KPSS sürecine katkı sunma & ÖA $_{36}$ & 1 & 2,1 \\
\hline
\end{tabular}

Türkçe öğretmeni adaylarının tamamı Metindilbilim dersinin Türkçe öğretmenliği lisans programında yer almasının gerekli olduğunu ifade etmişlerdir. Öğretmen adaylarının \%29,2'si Metindilbilim dersinin Türkçe öğretmenliği sürecinde kullanılacak bilgiler sunduğunu, \%27,1'i metin odaklı Türkçe eğitimine ve \%2,1'i metinlere yönelik etkinlik tasarlama sürecine katkı sunduğunu, $\% 12,5^{\prime} i$ metin kavramına ilişkin yanlış öğrenmelerini düzelttiğini ve yeni bilgiler kazandırdığını, \%12,5'i metinleri anlama ve anlamlandırma süreçlerine katkı sunduğunu belirtmiştir. Metindilbilim dersinin dil becerilerini geliştirme bağlamında gerekli olduğunu düşünen öğretmen adayları, okuma kazanımlarını gerçekleştirme $(\% 6,3)$ ve metin üretme etkinlikleri tasarlama sürecine $(\% 4,1)$ katkı sunduğunu ifade etmişlerdir. \%2,1'i ise Metindilbilim dersinin KPSS sürecine katkı sunduğunu belirtmiştir.

Türkçe öğretmeni adaylarının Metindilbilim dersinde edindikleri bilgi, beceri ve deneyimlerin meslek yaşamlarına katkı sunma durumuna ilişkin görüşleri Tablo 5'te sunulmuştur.

Tablo 5.

Türkçe Öğretmeni Adaylarının Metindilbilim Dersinde Edindikleri Bilgi, Beceri Ve Deneyimlerin Meslek Yaşamlarına Katkı Sunmasına Yönelik Görüşleri

\begin{tabular}{|c|c|c|c|c|}
\hline & Görüşler & Öğretmen Adayı & $f$ & $\%$ \\
\hline \multirow{10}{*}{$\stackrel{+}{\stackrel{\nu}{\nu}}$} & İyi bir Türkçe öğretmeni olma & $\begin{array}{l}\ddot{O}_{3}, \ddot{O}_{12}, \ddot{O A}_{14}, \ddot{O A}_{19}, \mathrm{Ö}_{20}, \\
\ddot{O A}_{21}, \ddot{O A}_{22}, \ddot{O A}_{34}, \mathrm{OA}_{37}\end{array}$ & 9 & 17,3 \\
\hline & Metne yönelik etkinlik tasarlama & 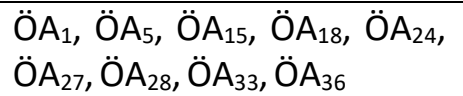 & 9 & 17,3 \\
\hline & $\begin{array}{l}\text { Metinleri işlevsel kullanma/metinlerin işlevini fark } \\
\text { etme }\end{array}$ & $\begin{array}{l}\ddot{O ̈}_{2}, \mathrm{Ö}_{6}, \mathrm{Ö}_{7}, \mathrm{Ö}_{10}, \mathrm{Ö}_{12}, \\
\ddot{O A}_{17}, \ddot{O A}_{29}\end{array}$ & 7 & 13,5 \\
\hline & Temel dil becerilerini geliştirme & $\begin{array}{l}\mathrm{Ö}_{14}, \mathrm{OA}_{15}, \mathrm{OA}_{16}, \mathrm{OA}_{18}, \mathrm{Ö}_{23}, \\
\mathrm{OA}_{25}, \ddot{O A}_{35}\end{array}$ & 7 & 13,5 \\
\hline & Metin kavramına yönelik yeni bilgiler edinme & $\begin{array}{l}\mathrm{ÖA}_{6}, \mathrm{Ö}_{8}, \mathrm{Ö}_{9}, \mathrm{Ö}_{10}, \mathrm{Ö}_{13}, \\
\mathrm{OA}_{29}\end{array}$ & 6 & 11,6 \\
\hline & Metin işleme süreci & $\mathrm{Ö}_{1}, \mathrm{ÖA}_{4}, \mathrm{Ö}_{12}, \mathrm{Ö}_{32}$ & 4 & 7,7 \\
\hline & Metinle dil/Türkçe öğretimi & $\mathrm{ÖA}_{5}, \mathrm{Ö}_{28}, \mathrm{Ö}_{31}, \mathrm{Ö}_{32}$ & 4 & 7,7 \\
\hline & Metin içi ilişkileri fark ettirme & $\ddot{O A}_{8}, \mathrm{ÖA}_{24}$ & 2 & 3,8 \\
\hline & Metin türü farkındalığı oluşturma & $\mathrm{ÖA}_{30}, \mathrm{Ö}_{31}$ & 2 & 3,8 \\
\hline & Olumlu katkıları oldu & $\ddot{O} A_{11}, \ddot{O} A_{26}$ & 2 & 3,8 \\
\hline
\end{tabular}

Türkçe öğretmeni adaylarının tamamı Metindilbilim dersinde edindikleri bilgi, beceri ve deneyimlerin meslek yaşamlarına katkı sunacağını belirtmişlerdir. Öğretmen adaylarının \%17,3'ü iyi bir Türkçe öğretmeni olmalarına katkı sunduğunu, \%3,8'i ise dersin meslek yaşamlarına olumlu katkıları olduğunu ifade etmiş ancak gerekçe sunmamışlardır.

Öğretmen adaylarının \%17,3'ü Türkçe derslerinde yer alan metinlere yönelik etkinlik tasarlama, \%13,5'i metinleri işlevsel kullanma, \%13,5'i temel dil becerilerini geliştirme, \% 7,7'si metin işleme sürecindeki öğretmenlik becerilerine ve metinle dil/Türkçe öğretimi yaklaşımlarına katkı sunduğunu belirtmişlerdir. Öğretmen adayları, metindilbilimin metin içi ilişkileri fark ettirme $(\% 3,8)$ ve metin türü farkındalığı kazandırma $(\% 3,8)$ bağlamında mesleki yaşamlarına katkı sunduğunu ifade etmişlerdir. 
Türkçe öğretmeni adaylarının Metindilbilim dersinin kendi metin çözümleme süreçlerine katkı sunma durumuna yönelik görüşlerine Tablo 6’ da yer verilmiştir.

Tablo 6.

Türkçe Öğretmeni Adaylarının Metindilbilim Dersinin Metin Çözümleme Süreçlerine Katkı Sunma Durumuna Yönelik Görüşleri

\begin{tabular}{|c|c|c|c|c|}
\hline & Görüşler & Katılımcı & $f$ & $\%$ \\
\hline \multirow{10}{*}{ 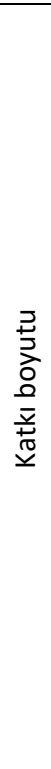 } & Metni anlama sürecine katkı & 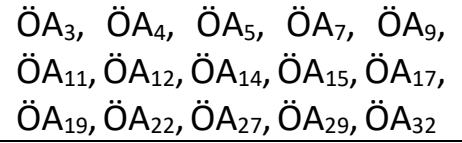 & 15 & $\begin{array}{l}33 \\
4\end{array}$ \\
\hline & Katkı sundu & $\begin{array}{l}\mathrm{ÖA}_{13}, \quad \mathrm{ÖA}_{16}, \quad \ddot{O ̈}_{25}, \quad \ddot{O ̈}_{26}, \\
\text { ÖA }_{30}, \mathrm{OA}_{33}, \mathrm{ÖA}_{34}, \mathrm{Ö}_{36}, \mathrm{ÖA}_{37}\end{array}$ & 9 & 20 \\
\hline & Metin içi dilsel ve anlamsal ilişkileri fark etme & $\begin{array}{l}\ddot{O A}_{1}, \mathrm{ÖA}_{8}, \mathrm{OA}_{12}, \mathrm{Ö}_{14}, \mathrm{ÖA}_{23} \text {, } \\
\mathrm{ÖA}_{24}, \mathrm{ÖA}_{28}, \mathrm{ÖA}_{38}\end{array}$ & 8 & $\begin{array}{l}17 \\
8\end{array}$ \\
\hline & Betimlemelerin işlevini fark etme & ÖA $_{1}$, ÖA $_{16}, \mathrm{ÖA}_{10}$ & 3 & 6,7 \\
\hline & Metnin derin yapısını kavrama & $\ddot{O ̈ A}_{6}, \mathrm{ÖA}_{18}, \ddot{O A}_{20}$ & 3 & 6,7 \\
\hline & Biçimden anlama ulaşma & $\mathrm{ÖA}_{10}, \mathrm{Ö}_{23}$ & 2 & 4,4 \\
\hline & $\begin{array}{l}\text { Metin kavramına bakış açısını değiştirme (sadece } \\
\text { yazılı ürünleri metin olarak kabul etme anlayışının } \\
\text { değişmesi) }\end{array}$ & $\ddot{O ̈ A}_{17}, \mathrm{ÖA}_{18}$ & 2 & 4,4 \\
\hline & Metinlerarası ilişki kurma & $\ddot{O ̈}_{2}$ & 1 & 2,2 \\
\hline & Metnin işlevini fark etme & $\mathrm{ÖA}_{21}$ & 1 & 2,2 \\
\hline & Metin unsurlarını belirleme (konu, ana fikir vb) & $\mathrm{ÖA}_{35}$ & 1 & 2,2 \\
\hline
\end{tabular}

Türkçe öğretmeni adaylarının tamamı, Metindilbilim dersinin kendi metin çözümleme süreçlerine katkı sağladığını ifade etmişlerdir. Ancak öğretmen adaylarının \%20'si Metindilbilim dersinin hangi bağlamlarda metin çözümleme süreçlerine katkı sağladığını ifade etmemiş, \%33,4’ü ise sadece metni anlama süreçlerine katkı sağladığını ifade etmiş ve bu ifadelerini detaylı biçimde açıklayamamışlardır. Bunun yanında metindilbilimin kendi metin çözümleme süreçlerine olan katkısını açıklayan öğretmen adayları da olmuştur.

Öğretmen adaylarının \%17,8'i Metindilbilim dersinin metin içi ilişkileri, \%6,7'si metinde kullanılan betimlemelerin işlevini fark etme, \%6,7'si metnin derin yapısını kavrama, \%4,4'ü ise biçimden anlama ulaşma becerilerine katkı sağladığını ifade etmişlerdir. Öğretmen adaylarının \%4,4'ü önceden sadece yazılı ürünleri metin olarak kabul ettiklerini ve Metindilbilim dersinin bu bakış açısını değiştirdiğini belirtmişlerdir.

Türkçe öğretmeni adaylarının Metindilbilim dersine ayrılan süreye ilişkin görüşleri Tablo 7'de sunulmuştur.

Tablo 7.

Türkçe Öğretmeni Adaylarının Metindilbilim Dersine Ayrılan Süreye Yönelik Görüşleri

\begin{tabular}{|c|c|c|c|}
\hline Görüşler & Katılımcılar & $f$ & $\%$ \\
\hline Yeterli & 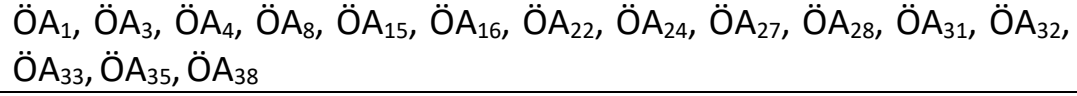 & 15 & 39,5 \\
\hline Kısmen yeterli & $\ddot{O ̈ A}_{5}, \ddot{O A}_{14}, \ddot{O A}_{19}, \mathrm{ÖA}_{29}, \mathrm{ÖA}_{34}, \mathrm{ÖA}_{36}$ & 6 & 15,8 \\
\hline Yetersiz & 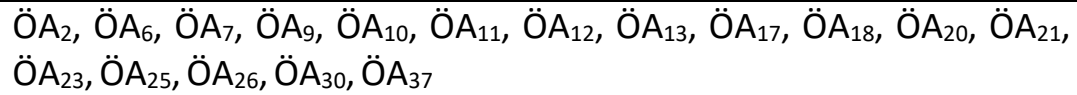 & 17 & 44,7 \\
\hline
\end{tabular}

Türkçe öğretmeni adaylarının \%39,5’i Metindilbilim dersine ayrılan sürenin yeterli olduğunu düşünürken \%15,8'i kısmen yeterli, \%44,7'si ise yetersiz olduğunu düşünmektedir. Ders süresini kısmen yeterli ve yetersiz bulan öğrenciler, metindilbilim yaklaşımını farklı metin türleri üzerinde görme ve 
ortaokul düzeyinde metindilbilim temelli etkinlikler tasarlama bağlamında ders süresinin artması gerektiğini vurgulamışlardır.

Türkçe öğretmeni adaylarının Metindilbilim dersine yönelik önerilerine Tablo 8'de yer verilmiştir.

Tablo 8.

Türkçe Öğretmeni Adaylarının Metindilbilim Dersine Yönelik Önerileri

\begin{tabular}{|c|c|c|c|}
\hline Görüssler & Katılımcılar & $f$ & $\%$ \\
\hline $\begin{array}{l}\text { Metinler üzerinde (farklı metin türleri) daha fazla } \\
\text { uygulama yapma }\end{array}$ & 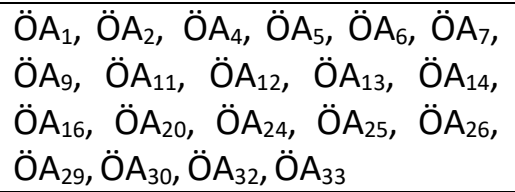 & 20 & $\begin{array}{l}34, \\
4\end{array}$ \\
\hline $\begin{array}{l}\text { Türkçe derslerinde kullanılabilecek etkinlik örneklerine } \\
\text { yer verme }\end{array}$ & 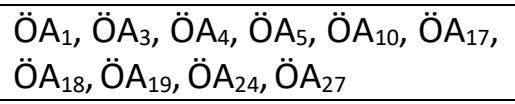 & 10 & $\begin{array}{ll}17 \\
2\end{array}$ \\
\hline Ders bu biçimiyle işlevsel /Önerim yok & 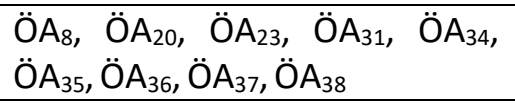 & 9 & $\begin{array}{l}15, \\
5\end{array}$ \\
\hline Teorik bilgi kısıtlı olmalı & 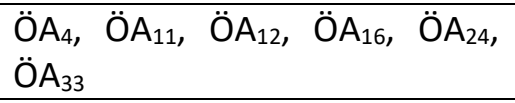 & 6 & $\begin{array}{l}10, \\
4\end{array}$ \\
\hline Ders saatinin daha fazla olması & $\begin{array}{l}\ddot{O ̈}_{6}, \quad O ̈ A_{10}, \quad O ̈ A_{12}, \quad O ̈ A_{14}, O ̈ A_{21}, \\
O A_{30}\end{array}$ & 6 & $\begin{array}{l}10, \\
4\end{array}$ \\
\hline Metindilbilimsel etkinlik tasarlama & $\ddot{O} A_{18}, O ̈ A_{19}, O ̈ A_{22}$ & 3 & 5,3 \\
\hline $\begin{array}{l}\text { Dil becerilerine yönelik lisans derslerinden önce } \\
\text { verilmeli }\end{array}$ & $\mathrm{Ö}_{5}, \mathrm{Ö}_{27}$ & 2 & 3,4 \\
\hline $\begin{array}{l}\text { Öğretmen adaylarının kendi metinleri üzerinde } \\
\text { metindilbilimsel çözümleme yapması }\end{array}$ & $\mathrm{ÖA}_{15}$ & 1 & 1,7 \\
\hline $\begin{array}{l}\text { Metindilbilimin dil becerilerine katkısına yönelik } \\
\text { etkinlikler tasarlama }\end{array}$ & $\mathrm{ÖA}_{28}$ & 1 & 1,7 \\
\hline
\end{tabular}

Türkçe öğretmeni adaylarının \%34,4'ü Metindilbilim dersinde farklı metin türleri üzerinde daha fazla uygulama yapılmasını, \%17,2'si Türkçe derslerinde kullanılabilecek metindilbilim temelli etkinlik örneklerine yer verilmesini, \%10,4'ü teorik bilginin daha az olması gerektiğini, \%10,4'ü ders saatinin artırılmasını, \%5,3'ü metindilbilim temelli etkinlik tasarlamak istediklerini ifade etmişlerdir. Öğretmen adaylarının \%3,4'ü dersin yer aldığı dönemle ilgili önerilerde bulunmuşlardır. Metindilbilim dersinin dil becerilerine yönelik okuma, dinleme, yazma ve konuşma eğitimi derslerinden daha önceki bir dönemde yer alması gerektiği yönünde öneride bulunmuşlardır. Öğretmen adaylarının \%15,5'i dersin bu şekliyle işlevsel olduğunu ve önerilerinin olmadığını ifade etmişlerdir.

\section{Tartışma ve Sonuç}

Bu araştırmada, Türkçe öğretmenliği lisans programında yer alan Metindilbilim dersine ilişkin Türkçe öğretmeni adaylarının görüş ve önerilerini belirlemek amaçlanmıştır. Türkçe öğretmeni adaylarının görüş ve önerilerinden hareketle Metindilbilim dersinin içeriğine ve yürütülmesine yönelik öneriler sunulmaya çalışılmıştır.

Araştırmaya katılan 38 Türkçe öğretmeni adayı, Metindilbilim dersinin Türkçe öğretmenliği lisans programında yer alması gerektiğini ifade etmiştir. Öğretmen adayları, Metindilbilim dersinin lisans programında yer almasının gerekli olduğuna yönelik farklı gerekçeler öne sürmüşlerdir. Bu gerekçeler Türkçe öğretmenliği sürecinde kullanılacak bilgiler kazandırma, metin odaklı Türkçe eğitimine katkı sunma, metin kavramına yönelik yeni bilgiler sunma ve yanlış öğrenmeleri düzeltme, metni anlama ve metin çözümleme süreçlerine katkı sunma, okuma becerisi kazanımlarını gerçekleştirme becerisini geliştirme ve metin türü farkındalığı kazandırmadır. Coşkun (2013, s. 260) bir öğretmenin, öğrencilerine metin oluşturma ve metni anlama eğitimi verebilmesi için öncelikle kendisinin metin bilgisi alanında bilgi ve beceriye sahip olması gerektiğini bu nedenle Türkçe 
öğretmenlerinin eğitiminde metin bilgisi vermeyi amaçlayan derslerin yer almasının gerekli olduğunu ifade eder. Aynı zamanda dil eğitiminde başarı sağlayan ülkelerin metindilbilim alanında yapılan çalışmaları ve yeni yöntemleri hızla eğitim alanına yansıttıklarını vurgular. Dolayısıyla Metindilbilim dersinin Türkçe öğretmenliği programında yer almasının bir zorunluluk olduğu söylenebilir. Türkçe öğretmeni adaylarının görüşleri dikkate alındığında Metindilbilim dersinin, Türkçe eğitimi alanı ve Türkçe öğretmenliği becerileri açısından önemini ve değerini fark ettikleri görülmektedir.

Türkçe öğretmeni adaylarının tamamı Metindilbilim dersinde edindikleri bilgi, deneyim ve becerilerin öğretmenlik becerilerine katkı sağladığını düşünmektedir. Öğretmen adaylarına göre Metindilbilim dersi iyi bir Türkçe öğretmeni olmayı, metinlere yönelik etkinlik tasarlama ve metin işleme süreçlerini nitelikli hâle getirmeyi, temel dil becerilerini geliştirme becerisi kazandırmayı, metinle Türkçe öğretimini, metin içi ilişkileri fark ettirmeyi ve öğrencilerine metin türü farkındalı̆ı kazandırmalarını sağlayacak nitelikte bir derstir. Türkçe Öğretim Programı metin çözümleme ve değerlendirme kazanımlarında büyük ölçekli yapı çözümlemeleri yer almaktadır. Dilidüzgün'e (2013) göre önemli olan öğretmenin bu kazanımları gerçekleştirme sürecinde metnin yüzey yapısında bulunan dilsel ve metinsel özellikleri irdeleyerek, ilişkilendirerek ortaya çıkarabilecek etkinlikler tasarlayabilmesidir. Bu etkinlikleri tasarlayabilen öğretmen, öğrencilerine metin bilinci kazandırma, metin üretme ve anlama becerilerini geliştirme noktasında başarılı olabilecektir. Metnin çok katmanlı yapısı göz önünde bulundurulduğunda, Türkçe öğretmeninin metnin dilsel özelliklerinin anlamı üzerinde etkili olduğunu sezdirebilmesi açısından metindilbilimin olanaklarından yararlanmasının önemli olduğu düşünülmektedir.

Türkçe öğretmeni adayları Metindilbilim dersinin, meslek yaşamlarına temel dil becerilerini geliştirme sürecine ve metinle Türkçe öğretimine katkı sunacağını belirtmişlerdir. Güneş'e (2013) göre dil öğretiminde metinlerin nasıl seçileceği ve işleneceği üzerinde sistemli çalışmalar yapılmakla birlikte dil becerilerini geliştirmek için metin öğretimi yerine metinle öğrenme yaklaşımı benimsenmektedir. Ancak Türkçe derslerinde nitelikli metinlerin kullanılması kadar metinlerin nasıl ele alındığı, çözümlendiği de önemlidir. Aynı zamanda Türkçe derslerinde metinlerle, temel dil becerilerinin geliştirilmesi amaçlanmaktadır. Öğrencilerin karşılaştıkları "metin türüne uygun strateji geliştirilebilmesi türe uygun okuma, dinleme, konuşma ve yazma yöntem ve tekniklerini kullanmakla gerçekleştirilebilir." (Çetinkaya Edizer, Dilidüzgün, Ak Başoğlu, Karagöz ve Yücelşen, 2018, s. 481). Coşkun'a (2013, s. 262) göre Türkçe eğitimi sürecinde önemli olan öğrencilerin dil bilgisel yapıların ne olduğunu ve türlerini ezberlemesi değil, bu dilsel birimlerin bir metnin alımlanmasına ve oluşumuna katkılarını görebilmesi ve bunları konuşma, dinleme, okuma ve yazma becerilerinde doğru biçimde kullanabilmesidir. Bu bağlamda, "Türkçe öğretiminde araştırma konusu metin olan ve metinlerin yapılarını ve işlevlerini çözerek onları belli metin gruplarına ayırmayı hedefleyen metindilbilimin bulgularından yararlanılması kaçınılmazdır." (Dilidüzgün, 2017, s. 119).

Türkçe öğretmeni adayları, Metindilbilim dersinin metin türü farkındalığı sağlama açısından da işlevsel olduğunu ifade etmişelerdir. Kaygısız (2018), metni basit biçimde çözümlemekten ziyade, metnin iletişimsel amacına bağlı olarak şekillenen söylem özelliklerinin ve bu özelliklerin yüzey yapıdaki yansıması olan yapı bileşenlerinin çözümlenmesi metin türüne ait bilişsel çevrene ulaşmada ve derin anlamanın gerçekleşmesinde son derece önemli olduğunu belirtir. Bozkurt (2019), "dil öğretimi ortamlarının temel amacı, dille etkileşme süreçlerindeki anlama ve anlatma etkinliklerini iyileştirmektir ve bu iyileştirmede temel görevlerden birini, metin türü farkındalığının (edinci)" üstlendiğini ifade etmiştir. Metin türü farkındalığı sadece anlama becerilerinin eğitiminde değil anlatma becerilerinin eğitiminde de işlevsel bir rol almaktadır. Dilidüzgün'e (2017) göre metin türlerine özgü işlevsel, yapısal, anlamsal ve biçimsel özelliklerin ve metinlerin nasıl düzenlendiklerinin/kurgulandıklarının metindilbilimsel çözümlemelerle öğretilmesi gerekir. Bu öğretim, öğrencilerin karşılaştıkları metinleri doğru biçimde anlamalarını ve iletişimsel amacına uygun farklı türde metinler üretmelerini sağlayabilir.

Türkçe öğretmeni adaylarının tamamı, Metindilbilim dersinin kendi metin çözümleme süreçlerine katkı sunduğu görüşünde birleşmiştir. Öğretmen adayları Metindilbilim dersinin metni anlama, metin içi dilsel ve anlamsal ilişkileri belirleme, metnin derin yapısını kavrama, biçimden anlama ulaşma ve metin kavramına yönelik yanlış öğrenmeleri düzeltme, metin kavramına bakışlarını değiştirme açısından katkı sağladığını ifade etmişlerdir. Kendi metin çözümleme ve alımlama süreçlerini 
düzenleyen ve metnin biçimi ile anlamı arasında ilişki kuran Türkçe öğretmeni adaylarının bu becerilerini mesleki yaşamlarına da aktarabilecekleri ve bu aktarımı metindilbilimin olanaklarıyla gerçekleştirebilecekleri söylenebilir.

Türkçe öğretmeni adaylarının 17'si Metindilbilim dersine ayrılan süreyi yetersiz, 15 'i yeterli, 6 'sı ise kısmen yeterli bulmuşlardır. Metindilbilim dersine ayrılan süreyi yeterli bulan öğretmen adayları bu sürenin kuramsal bilgi ve uygulama çalışmaları için uygun olduğunu ifade ederken derse ayrılan sürenin yetersiz olduğunu ifade edenler daha fazla metin üzerinde uygulama yapabilmek ve Türkçe eğitimine yönelik etkinlik örnekleri görebilmek/etkinlik tasarlayabilmek için ders süresinin artırılması gerektiğini belirtmişlerdir. Derse ayrılan sürenin kısmen yeterli olduğunu ifade eden öğretmen adayları ise daha fazla uygulama çalışması yapılabilmesi için ders süresinin artırılmasının gerekli olduğunu söylemişlerdir.

Türkçe öğretmeni adaylarının Metindilbilim dersine yönelik önerileri incelendiğinde adayların en çok uygulama çalışmalarının artması yönünde görüş bildirdiği tespit edilmiştir. Öğretmen adayları Metindilbilim dersinde farklı metin türleri üzerinde daha fazla çözümleme yapmak, metindilbilimsel etkinlik örnekleri incelemek, ders saatinin artırılması, metindilbilimsel etkinlik tasarlama gibi önerileri dersin uygulama boyutuna ağırlık verilmesinin gerekli olduğunu göstermektedir. Metindilbilimle ilgili kuramsal bilgilere sahip olmak öğretmen adaylarının metin çözümleme süreçlerine ve öğretmenlik becerilerine katkı sunacaktır. Ancak öğretmen adaylarının, Türkçe derslerinde işlenen metinlere yönelik metindilbilim odaklı etkinlikler tasarlayabilmeleri için metindilbilimsel etkinlik tasarlama süreçlerini bilmeleri ve metindilbilimi dil becerilerini geliştirme bağlamında işlevsel olarak nasıl kullanılacağını uygulama yaparak görmeleri gerekir. Dilidüzgün (2013) Metindilbilim dersinin öğretmen adaylarının okuma kazanımlarını gerçekleştirici nitelikte etkinlikler hazırlama becerisini geliştirmeye yönelik etkisini saptamayı amaçladığı çalışmasında "öğretmen adayları Metindilbilim dersinde geliştirdikleri metin bilinci ve bilgisi doğrultusunda metindeki dilsel, dilbilimsel ve metinsel ilişkilerden yola çıkarak, her metnin kendine özgü yapı ve kurgusunu çözümleyerek metin yapısına uygun etkinlik geliştirme becerilerini geliştirdiklerini belirtmişlerdir.". Araştırmanın bu sonucundan hareketle Türkçe öğretmeni adaylarının dil becerilerine yönelik etkinlik tasarlama becerilerini geliştirebilmeleri için Metindilbilim dersinin uygulama yönünün ön plana çıkarılmasının gerekli olduğu söylenebilir.

Türkçe öğretmeni adaylarının derse yönelik dikkat çeken önerilerinden biri ise Metindilbilim dersinin dil becerilerinin eğitimine yönelik (Okuma Eğitimi, Yazma Eğitimi, Konuşma Eğitimi ve Dinleme Eğitimi) derslerinden önce yer alması gerektiğine yöneliktir. Ders sürecinde de bu görüşleri dile getiren öğretmen adayları, dil becerilerini geliştirme bağlamında Metindilbilim dersinin hem anlama hem de anlatma becerilerinin eğitimine katkı sunacağını ifade etmişlerdir. Bu bağlamda dil becerilerine yönelik dersleri almadan ve önce Metindilbilim dersi ile karşılaşmaları gerektiğini ve dersin dil becerilerine yönelik etkinlik tasarlama süreçlerine katkı sunacağını belirtmişlerdir.

Sonuç olarak Türkçe öğretmeni adayları, Metindilbilim dersinin Türkçe öğretmenliği lisans programında yer almasının gerekli olduğunu, mesleki yaşamlarına ve kendi metin çözümleme süreçlerine katkı sunduğunu, dersin uygulama boyutunun daha fazla olabilmesi için ders süresinin artırımasının gerektiğini ve dersin kuramsal bilgilerle birlikte Türkçe eğitiminde kullanılabilecek metindilbilimsel odaklı etkinlik tasarlama süreçlerine katkı sunacak biçimde düzenlenmesi gerektiğini ifade etmişlerdir. Öğretmen adaylarının metinleri işlevsel biçimde kullanabilmeleri, biçim ve anlam arasında ilişki kurabilmeleri, dil bilgisinin bir amaç değil anlama ve anlatma becerilerinin geliştirilmesi için bir araç olduğunu fark edebilmeleri için Metindilbilim dersini almalarının olumlu sonuçlar ortaya çıkaracağı düşünülmektedir.

\section{Araştırma ve Yayın Etiği}

Bu çalışmada "Yükseköğretim Kurumları Bilimsel Araştırma ve Yayın Etiği Yönergesi" kapsamında uyulması belirtilen tüm kurallara uyulmuştur. Yönergenin ikinci bölümü olan "Bilimsel Araştırma ve Yayın Etiğine Aykırı Eylemler" başlığı altında belirtilen eylemlerden hiçbiri gerçekleştirilmemiştir. 


\section{Etik Kurul İni}

Kurul adı = Atatürk Üniversitesi Eğitim Bilimleri Enstitüsü Birim Etik Kurulu

Karar tarihi $=07.06 .2021$

Belge sayı numarası= E-29202147-300-2100147236-06/10 sayılı karar

\section{Yazarların Katkı Oranı}

Araştırma tek yazarlı olduğu için yazarın katkı oranı \%100'dür.

\section{Çıkar Çatışması}

Araştırmada çıkar çatışması oluşturacak herhangi bir durum söz konusu değildir.

\section{Kaynaklar}

Akyüz, E., Özcan, Ş. \& Altıparmak, H. M. (2015). Türkçe öğretmeni adaylarının Türkçe özel öğretim yöntemleri dersine ilişkin görüşleri. Dil Eğitimi ve Araştırmaları Dergisi, 1(1), 65-76.

Berg, B. L. \& Lune, H. (2019). Sosyal bilimlerde Nitel Araştırma Yöntemleri. H. Aydın (Çev. Ed.). Konya: Eğitim Kitabevi.

Bozkurt, B. Ü. (2019). Türkçe öğretmeni adaylarının metin türlerini kavramlaştırma eğilimleri ve tür farkındalıkları. Bolu Abant İzzet Baysal Üniversitesi Eğitim Fakültesi Dergisi, 19(1), 86-102.

Börekçi, M. (2009). Türk dili edebiyatı ve Türkçe öğretmenlerinin yetiştirilmesi sürecinde dilbilim ve Türkçe öğretimi. Turkish Studies, 4(3), 419-429.

Ceran, D. (2012). Türkçe öğretmeni adaylarının konuşma eğitimi dersine yönelik tutumlarının değerlendirilmesi. The Journal of Academic Social Science Studies, 5(8), 337-358.

Ceran, D. (2013). Türkçe öğretmeni adaylarının yazma eğitimi dersine yönelik tutumlarının değerlendirilmesi. Turkish Studies, 8(1), 1151-1169.

Creswell, J. W. (2017). Araştırma deseni. S. B. Demir (Çev. Ed.). Ankara: Eğiten Kitap.

Coşkun E. (2013). Türkçe öğretiminde metin bilgisi. Ahmet Kırkkılıç \& Hayati Akyol (Ed.), ilköğretimde Türkçe öğretimi içinde (s. 231-283). Ankara: Pegem Akademi Yayınları.

Çetinkaya Edizer, Z., Dilidüzgün, Ş., Ak Başoğlu, D., Karagöz, M., \& Yücelşen, N. (2018). Türkçe öğretiminde üstbilişsel okuma stratejileri ile okuma yöntem-tekniklerinin metin türüne göre değerlendirilmesi. Adıyaman Üniversitesi Sosyal Bilimler Enstitüsü Dergisi, 29, 479-511.

Çıkrıkçı, S. S. (2007). Metindilbilimin temel kavramlarının anadili öğretimi süreci açısından değerlendirilmesi. Dil Dergisi, 138, 43-57.

Çoban, A. (2010). Türkçe öğretmenliği lisans programlarının değerlendirilmesi. Turkish Studies, 5(3), 959-976.

Dilidüzgün, Ş. (2013). Metindilibilim dersinin Türkçe öğretmen adaylarının okuma etkinlikleri geliştirme yetilerine etkisi. Turkish Studies, 8(1), 1239-1258.

Dilidüzgün, Ş. (2017). Metindilbilim ve Türkçe öğretimi. Ankara: Anı Yayınları.

Doğan, B. \& Özberk, E. H. (2013). Türkçe öğretmeni adaylarının tiyatro ve drama uygulamaları dersine ilişkin tutumlarının belirlenmesi. Eğitim ve Öğretim Araştırmaları Dergisi, 2(1), 253-263.

Durukan, E. \& Maden, S. (2011). Türkçe öğretmeni adaylarının Türkçe öğretmenliği lisans programına yönelik görüşler. Kastamonu Eğitim Dergisi, 19(2), 555-566.

Eyüp, B. (2019). Türkçe öğretmeni adaylarının dinleme eğitimi dersiyle ilgili görüşleri. Uluslararası Türkçe Edebiyat Kültür Eğitim Dergisi, 8(3), 1773-1795.

Güneş, F. (2013). Türkçede metin öğretimi yerine metinle öğrenme. Adıyaman Üniversitesi Sosyal Bilimler Enstitüsü Dergisi, 6(11), 604-637.

Güzel. A. (2003). Türkçe'nin eğitimi-öğretimi bölümlerinde kurulması gerekli görülen anabilim dalları hakkında yeni projelerimiz. Selçuk Üniversitesi Türkiyat Araştırmaları Dergisi, 13, 63- 86.

Hirik, S. (2018). Öğretmen adaylarının cümle bilgisi dersine ilişkin görüşlerinin değerlendirilmesi. Ulus/ararası Sosyal Bilimler Eğitimi Dergisi, 4(2), 90-111.

Işık, A., Çiltaş, A. \& Baş, F. (2010). Öğretmen yetiştirme ve öğretmenlik mesleği. Atatürk Üniversitesi Sosyal Bilimler Enstitüsü Dergisi, 14(1), 53-62. 
Kaygısız, Ç. (2018). Okuma eğitiminde metin yapısı farkındalığı: bilgilendirici metin örneği. Turkish Studies, 13(4), 823-840.

Kahya, H. (2020). Türkçe öğretmeni adayları Osmanlı Türkçesi dersi hakkında ne düşünüyor?. Türkiyat Mecmuası, 30(1), 129-160.

Kansızoğlu, H. B. (2016). Türkçe öğretmeni adaylarının medya okuryazarlığı dersine yönelik görüşleri. ilköğretim Online, 15(2), 469-486.

Kavcar, C. (1993). Yeni Türk edebiyatı öğretimi. Ankara Üniversitesi Eğitim Bilimleri Fakültesi Dergisi, 26(1), 29-38.

Kavcar, C. (2002). Cumhuriyet döneminde dal öğretmeni yetiştirme. Ankara Üniversitesi Eğitim Bilimleri Fakültesi Dergisi, 35(1), 1-14.

MEB, (2006). Ilköğretim Türkçe dersi (6, 7, 8. sınıflar) öğretim programı. Ankara: Milli Eğitim Basımevi. Merriam, S. B. (2018). Nitel araştırma desen ve uygulama için bir rehber. Ankara: Nobel Yayınları.

Onan, B. (2015) Derin yapı yüzey yapı ilişkisi bağlamında temel dil becerileri üzerine bir analiz çalışması. Ana Dili Eğitimi Dergisi, 3(3), 91-110.

Özkan, B. (2010). Türkçe öğretmeni adaylarının 'anlama teknikleri' ve 'anlatma teknikleri' derslerine yönelik görüşleri. e-Journal of New World Sciences Academy, 6(3), 2123-2132.

Özkan, B. \& Şahbaz, N. (2011). Türkçe öğretmeni adaylarının alan derslerinin işlevselliğine yönelik görüşleri. Sakarya University Journal of Education, 1(1), 32-43.

Sevim, O. (2011). Türkçe öğretmeni adaylarının topluma hizmet uygulamaları dersine yönelik düşünceleri: Atatürk Üniversitesi örneği. EKEV Akademi Dergisi, 15(48), 293-302.

Sevim, O. \& Şeref, i. (2015). Türkçe öğretmen adaylarının okuma eğitimi dersiyle ilgili görüş ve önerileri. EKEV Akdemi Dergisi, 19(61), 365-378.

Sönmez, V. (2007). Program geliştirmede öğretmen el kitabı. Ankara: Anı Yayınları.

Stebler, M. Z. \& Aykaç, N. (2019). 2018 Türkçe öğretmenliği lisans programının öğretim elemanlarının görüşleri doğrultusunda değerlendirilmesi. Dil Eğitimi ve Araştırmaları Dergisi, 5(2), 116-138.

Şenöz Ayata, C. (2005). Metindilbilim ve Türkçe. İstanbul: Multilingual Yayınları.

Tüm, G. (2016). Türkçe öğretmen adayları ve uygulama öğretmenlerinin öğretmenlik uygulaması dersleri hakkındaki görüş ve değerlendirmeleri. International Journal of Language Academy, 4(3), 1-17.

Ürün Karahan, B. (2016). Türkçe öğretmeni adaylarının öğretim teknolojileri ve materyal tasarımı dersine yönelik tutumlarının incelenmesi (Kafkas Üniversitesi örneği). Okuma Yazma Eğitimi Araştırmaları, 4(2), 26-35.

Yalap, H., Demirgüneş, S. \& Akay, A. (2020). Türkçe eğitimi bölümlerinde eğitim programı nasıl olmalıdır?. Uluslararası Medeniyet Çalışmaları Dergisi, 5(2), 230-254.

Yıldırım, A. \& Şimşek, H. (2000). Sosyal bilimlerde nitel araştırma yöntemleri. Ankara: Seçkin yayınları.

Yılmaz, O. (2016). Türkçe öğretmeni adaylarının çocuk edebiyatı dersine ilişkin düşünceleri üzerine olgubilimsel bir araştırma. Sakarya Üniversitesi Eğitim Fakültesi Dergisi, 31, 33-59.

YÖK, (1998). Eğitim fakültesi öğretmen yetiştirme lisans programları. Yükseköğretim Kurulu Yayını.

YÖK, (2007). Eğitim fakültesi öğretmen yetiştirme lisans programları. Yükseköğretim Kurulu Yayını.

YÖK (2018). Türkçe öğretmenliği lisans programı. Yükseköğretim Kurulu Yayını.

\section{Introduction}

\section{Extended Abstract}

The education system is formed by the joint operation of many different components. The quality of the components in the system also determines the quality of education. According to Kavcar (2002), the teacher is the most important component of the educational system, and qualified teachers are the foundation of quality education. Turkish teachers' well-equipped training is dependent on the courses and course contents in undergraduate programs accepted as pre-service education, just as it is in all other teaching disciplines.

Contemporary approaches that argue that grammar is a tool in the process of developing basic language abilities should be favoured over conventional approaches that teach grammar as a separate discipline. At the same time, considering the natural relationship between language and thought, it is 
concluded that language education is also a thinking education (Börekçi, 2009, p. 422). In this context, it is critical for Turkish teacher candidates to achieve field knowledge about language and thinking skills in undergraduate programs that are instrumental in the preparation of Turkish teachers, and to encounter courses and course content that will allow them to turn this content knowledge into a skill.

The use of language in language teaching is emphasized in contemporary teaching approaches, which argue that text should be the primary language unit. While selecting qualified texts is one of the most essential criteria in determining the quality of teaching, there is a significant challenge with determining how to approach the chosen texts. According to Dilidüzgün (2013), studying and assessing a text requires discovering the relationships between the language elements that make up the text's meaning and breaking the text into functional portions. It highlights that the activities for the texts should have contents and features that are unique to each text and reveal the relationships that are particular to each text type. The functional use of texts is critical in terms of students seeing language structures in context, comprehending the relationship between language structures and meaning, and structuring the interpretation process accordingly. In this context, it is necessary to benefit from the possibilities of text linguistics, which aims to â€œreveal the structures of the texts, that is, the grammatical and contextual forms and communicative functions of the texts and show them with practical examples (Şenöz Ayata, 2005, p. 22). When we consider the relationship between text linguistics and Turkish education, we can conclude that it is critical for Turkish teachers who teach Turkish classes to have the knowledge and skills to recognize the value of text linguistics in Turkish education and to incorporate text linguistics tools into their lessons.

\section{Method}

The basic qualitative research design, which is one of the qualitative research models, was employed in this study. The study group was generated using one of the purposeful sampling approaches, easily accessible case sampling. The study group of the research consists of 38 teacher candidates studying at Ataturk University Kazım Karabekir Faculty of Education, Department of Turkish Education in the 2020-2021 academic year. Research data were collected by interview technique. The data collection tool for this study was a semi-structured written interview form, prepared by the researcher. Five open-ended questions were provided in the interview form. Research data was analyzed by using content analysis technique.

\section{Result and Discussion}

All the Turkish teacher candidates stated that the text linguistics course should be included in the Turkish teaching undergraduate program, and the knowledge, skills, and experiences gained in the text linguistics course will contribute to their professional careers. The text linguistics course helped all Turkish teacher candidates in their text analysis procedures, they claimed. However, $20 \%$ of teacher candidates could not express in which context the text linguistics course helped with text analysis, while $33.4 \%$ claimed it just helped with text comprehension and could not explain these statements in detail. While $39.5 \%$ of Turkish teacher candidates believe the time allocated to text linguistics is adequate, $15.8 \%$ believe it is just partially adequate, and $44.7 \%$ think it is insufficient. $34.4 \%$ of Turkish teacher candidates stated that more applications should be made on different text types in the text linguistics course, $17.2 \%$ of them said that text linguistics-based activities that can be used in Turkish lessons should be included, $10.4 \%$ said that theoretical knowledge should be less, $10.4 \%$ stated that the course hours should be increased, and $5.3 \%$ said that they wanted to design activities based on text linguistics.

38 Turkish teacher candidates who took part in the research stated that the text linguistics course should be included in the Turkish language teaching undergraduate curriculum. Pre-service teachers argued for a text linguistics course to be included in the undergraduate program for a variety of reasons. These reasons include providing information for use in Turkish teaching, contributing to text-oriented Turkish education, presenting new information about the concept of text and correcting mislearning, contributing to text comprehension and text analysis processes, improving the ability to realize reading skills, and raising text type awareness. 
All Turkish teacher candidates think that the knowledge, experience, and skills they have acquired in the Text linguistics course contribute to their teaching skills. According to teacher candidates, the text linguistics course is a course that will enable them to be a good Turkish teacher, to design activities for texts and to make text processing processes quality, to develop basic language skills, to teach Turkish with text, to realize relationships within the text, and to make students aware of text type.

All Turkish teacher candidates agreed that the text linguistics course contributed to their text analysis processes. The teacher candidates stated that the text linguistics course helped them understand the text, determine linguistic and semantic relationships within the text, comprehend the deep structure of the text, deduce meaning from form, correct misconceptions about the concept of text, and change their perspectives on the concept of text.

The time allocated to the text linguistics course was deemed insufficient by 17 Turkish teacher candidates, sufficient by 15 , and partially sufficient by 6 . While those who thought the time allocated to the text linguistics course was adequate stated that it was sufficient for theoretical knowledge and application studies, those who thought the time allocated to the course was insufficient stated that the course duration should be increased to be able to practice on more texts and see examples of Turkish education activities.

When the Turkish teacher candidates' proposals for the text linguistics course were investigated, it was discovered that they overwhelmingly voiced support for expanding application studies. Teacher candidates' suggestions, such as completing more text analysis in the text linguistics lesson, looking at examples of text linguistics activities, increasing the course hours, and devising text linguistics activities, reveal that the application dimension of the lesson must be prioritized.

Regarding the teaching of the text linguistics course in the Turkish teaching undergraduate program, the following proposals can be made:

1. Text linguistics should not be viewed as a course that solely provides theoretical material; rather, it should be organized in such a way that Turkish teacher candidates can explore various text types.

2. The text linguistics course is a course that will enable Turkish teacher candidates to design text-oriented activities. For this reason, text linguistics courses should contain practices that will aid Turkish teacher candidates' capacity to construct activities based on text linguistics.

3. The course's time might be extended in order to cover the course's application dimension more thoroughly.

4. The text linguistics course can be taken before the language skills education courses (Speaking Education, Reading Education, Listening Education, and Writing Education) in the Turkish teaching undergraduate program to take advantage of the possibilities of text linguistics in the context of developing language skills. 